\title{
Oral Communication Apprehension in Graduate Accounting Students: an epidemiological study from Portugal
}

\author{
Aprehensión comunicativa oral en estudiantes de contabilidad: un \\ estudio epidemiológico en Portugal
}

Francisco Carreira (francisco.carreira@esce.ips.pt)

Setúbal Polytechnique, Campus do IPS - Estefanilha, Setúbal, (Portugal)

https://orcid.org /0000-0001-9913-4698

Rui Silva (rui.silva@utad.pt)

University of Trás-Os-Montes and Alto Douro, CETRAD, Vila Real, (Portugal)

https://orcid.org/0000-0002-0283-9462

Amélia Ferreira da Silva (acfs@iscap.ipp.pt)

Porto Polytechnique, CEOS, Porto,

https://orcid.org/0000-0002-8366-9863

Anabela Martins Silva (anabela@eeg.uminho.pt)

University of Minho, Braga, (Portugal)

https://orcid.org/0000-0002-0197-9914

https://dx.doi.org/10.12795/EDUCADE.2021.i12.05

\begin{abstract}
RESUMEN: La cuarta revolución industrial está cambiando el trabajo diario de la contabilidad. Los robots están realizando la mayoría de las tareas técnicas de contabilidad. Por ello, se pide a los contables que desarrollen sus habilidades transversales, es decir, habilidades de comunicación, de presentación de negocios y otras habilidades interpersonales. En el desafiante entorno actual, las habilidades de comunicación oral siguen siendo cruciales para el éxito académico y profesional.

Esta investigación explora la aprehensión comunicativa oral de los estudiantes. El objetivo principal de este estudio fue describir la distribución epidemiológica de las manifestaciones subjetivas de la ansiedad en la comunicación oral en el universo de estudiantes de contabilidad que asistieron a las diversas instituciones académicas portuguesas en junio de 2020. Para ello, los autores del estudio pusieron a disposición, en Internet, una versión en portugués de una escala de autoadministrada Los principales resultados mostraron que, en un total de 813 estudiantes analizados, 161 (20\%) mostraron altas puntuaciones de aprensión comunicativa oral. Este resultado demuestra que, aunque los datos medios generales muestran valores aceptables (50 a 80), esto no significa que no haya estudiantes que experimenten este tipo de problema de aprensión en contextos de educación superior.

Esta investigación presenta una importante contribución al conjunto de la literatura, ya que permitió evaluar el nivel de aprehensión de la comunicación oral de los estudiantes de contabilidad portugueses. Se trata de un estudio nunca antes realizado en Portugal en el ámbito de la Contabilidad. En futuras investigaciones, los resultados podrán ser extrapolados a otras comunidades nacionales e internacionales.
\end{abstract}

PALABRAS CLAVE: aprensión comunicativa oral; estudiantes de contabilidad; educación superior.

Artículo de investigación. Recibido: 23-06-21 - Revisado 11-09-21, 27-09-21, 16-11-21, 09-12-21 Aceptado: 15-12-21

Licencia Creative Commons BY NC ND $\cdot 2021 \cdot$ Universidad de Sevilla - AECA

This work is financed by Portuguese national funds through FCT - Fundação para a Ciência e Tecnologia, under the project UIDB/05422/2020 and the project UIDB/040 $11 / 2020$. 


\begin{abstract}
The $4^{\text {th }}$ Industrial Revolution is changing accounting day-to-day working. Robots are performing most technical accounting tasks. So, accountants are being asked to develop their soft skills, namely communication skills, business presentation skills, and other interpersonal skills. In today's challenging environment, oral communication skills remain crucial for academic and professional success.

This research explores the Oral Communication Apprehension of students. The main objective of this study was to characterize the epidemiological distribution of the subjective manifestations of anxiety in oral communications in the universe of accounting students who attended the various Portuguese academic institutions in June 2020. For this purpose, the authors of the study provided, on the internet, a Portuguese language version of a self-completion scale. The main findings showed that in a total of 813 students analysed, 161 (20\%) showed high Oral Communication Apprehension scores. This result shows that although the general average data shows acceptable values (50 to 80), this does not mean that there are no students who experience this kind of apprehension problem in higher education contexts.

This investigation presents an important contribution to the body of literature since it allowed to evaluate the level of oral communication apprehension of Portuguese accounting students who study this area of knowledge. This is a study never done before in Portugal in the Accounting field. In future investigations, the results may be extrapolated to other national and international communities.
\end{abstract}

KEYWORDS: Oral Communication Apprehension; Accounting Students; Higher Education

\title{
1. INTRODUCTION
}

Nowadays, there is a strong consensus that education is the basis for the development of a nation. Politicians, families, educational administrations, public agencies, international organizations, between others, operate in the belief that "in the labour market and in life, education is worth the effort" (OECD, 2015:1). But this has not always been the case. Indeed, as stated by Bills (2016:241), "the idea that economic growth relies heavily on the expansion of schooling and the related idea that the chief rationale for expansion of schooling is economic development are both of relatively recent vintage". A major goal of Higher Education Institution is to train its graduates with the skills required to be successful in nowadays competitive, disruptive, innovation-driven, and global labor market. But "to succeed in the labour market, individuals need a mix of knowledge and skills" (OECD, 2017:26) in a moving world.

Accounting is the language of modern organizations and the business community. Thus, once organizations move in an ever-changing environment, accountants are constantly under pressure. They must adapt and reinvent themselves to meet organizations' needs. Digital transformation of economy and society demands to accountants a balanced frame of technical and soft skills. The $4^{\text {th }}$ Industrial Revolution is changing accounting dayto-day working. Robots are performing most technical accounting tasks and activities. So, accountants are being asked to develop their soft skills, namely communication skills, business presentation skills, and other interpersonal skills. The complex nature of accounting and its changing course over the history of businesses suggests that the digital transformation of society will bring new challenges for the accounting professional of the XXI century. Under the influence of the digital environment, the demands and requirements for employees' competencies are changing, and technical skills are losing space for soft skills. These circumstances made it urgent to rethink the training and curricula of accounting university graduates. These trends reflect the need to improve the mechanisms of adaptation of graduates in the labor market through the interaction of educational organizations and enterprises. 
In today's challenging environment, oral communication skills remain crucial for academic and professional success. Oral communication consists of expressing thoughts, beliefs, ideas, and other messages through verbal speech, and it plays a critical role in the interaction of students' lives. According to Gray (2010:40), "international research findings and anecdotal evidence alike suggest that new accountancy graduates often begin their careers with inadequate oral communication skills".

The Personal Report of Communication Apprehension (PRCA-24) scale allows foreseeing social interaction behaviors that vary according to Communication Apprehension (CA) levels (Murphy \& Weber, 2019). Communication Apprehension can be explained by genetic and biological factors (Hunsaker, Kelly, \& Duran, 1999). Over time, this scale has proven to be effective in measuring oral apprehension of students at different levels of education in diverse and multidisciplinary investigations, which makes it an extremely relevant instrument. However, although this scale has been extensively evaluated since its first validation, with a greater incidence in the last decade of research, there were only found two studies where it was validated in higher education students who study curricular accounting units (Coetzee, Schmulian, \& Kotze, 2014; Hassall, Arquero, Joyce, \& Gonzalez, 2013) and there was not found any study focused on Portuguese students. The PRCA-24 application only in two studies focused on accounting learning turns out to be scarce, given the suspected importance of this phenomenon on students in this area of knowledge where communication skills are vital. Besides, students know that communication skills are critical to compete in the labor market (Debnath et al., 2012). The existing differences in CA, measured longitudinally, prove that students show improvements in communication rates over time, showing that they are more able to communicate in public due to their increasing feelings of confidence (Hancock, Stone, Brundage, \& Zeigler, 2010; Loureiro, Loureiro, \& Silva, 2020). Regarding communication difficulties, students with high apprehension in oral communication contexts have less intense language, greater verbal productivity, more varied vocabulary, more complex language, and less comprehensible verbalization (McCroskey \& Beatty, 1984). However, CA levels decrease with age, professional experience, and habit on giving presentations (Marcel, 2019). To solve this problem, there are basic oral and public expression courses that allow the reduction of communication apprehension, revealing that this type of course can allow the improvement of the participants' communication levels (Rose, Rancer, \& Crannell, 1993; Whitworth \& Cochran, 1996). This scale has been questioned by several authors who mention that it does not have the capacity to explain interpersonal behavior because it does not have reliable variance to be applied to the contexts that are not focused on public entities (Porter, 1981). In another study, the scale was tested in its various dimensions, and it was found that it can be divided into seven factors that allow greater understanding and analysis of the communication context, communication modes, communication types, attitudes towards communication and the history of communication processes (Burgoon \& Hale, 1983). In this sense, the need to apply and validate the scale to different contexts and samples related to the teaching-learning process in the accounting field makes the present research study academically relevant due to the scarcity of studies in this area of scientific and academic knowledge. The main purpose of this study is to measure the oral apprehension of accounting students in Portuguese higher education.

The rest of paper is structured as follows. Part two reviews the literature the communication apprehension among students in the management and accounting field. Part three explains the research methodology, namely all procedures applied in sample selection, measure instrument validity and reliability, data collection, and data analysis. In part four we present, interpret, and discusses the results. Finally, we provide the main conclusions and the futures research direction. 


\section{RELEVANCE OF NON-TECHNICAL SKILLS IN ACCOUNTING: COMMUNICATION SKILLS}

Understanding skills needs in the labour market is complex since they can vary over time and from one location to another. The profile of skills expected to be developed by accounting graduates became a recurring space of debate between academic researchers and professional bodies (AAA, 1986; AICPA, 1999; 2001; IFAC,2010; IAESB, 2014; Siegel \& Sorensen, 1999). Earlier research focused on the good technical, professional, and discipline-specific knowledge and skills that distinguish accountants from other professional. Thus, the rules required by professional bodies and the gap between university curricula and labour market were at the center of the debate (Gammie \& Joyce, 2009; Hassall, Joyce, Arquero, \& Donoso, 2005). While technical skills are still valued, the need for more attention to transversal skill has been long recognized in accounting literature. An important reference on the theme is the Bedford Report, Committee on the Future Structure, Content, and Scope of Accounting Education (American Accounting Association, 1986). This document noticed the gap between what accountants do and what accounting educators teach and emphasized the needs for a broader education, were soft skills play an import role. Since then, many other professional and academic associations have published reports and statements expressing their perspective of the ideal profile of professional accountant. Even though there is a high predominance of technical skills, the opinions expressed in the published statements show a growing consensus around the idea that non-technical skills are necessary requisite for accountants to be able to perform their duties (Hassall et al, 2005).

Between non-technical skills, the communication skills appear at the top (Hassall et al, 2005). Indeed, the literature demonstrates that practitioners have regularly observed that new accountants show poor communication skills (Douglas \& Sigband, 1984). According to Arquero et al (2001:301) the group of communication skills "includes the ability to present and defend views and the results of one's own work, both oral or in writing and in formal or informal settings. Also included is the capability to locate, obtain, organize and use information from printed, human or electronic sources".

The study coordinated by Robert Half Finance and Accounting (www.robert halffinance.com) put the emphasis on interpersonal and critical-thinking skills. In this study, oral and written communication skills are identified as essential skills for accountants (Bloom \& Myring, 2008). Under this perspective, "although such skills are difficult to teach, they can be promoted or encouraged throughout a curriculum" (Bloom \& Myring, 2008:66). As stated by Parker (2001:447), "the profile of the accountant as beancounter is becoming increasingly distanced from the work in which accountants are becoming engaged". So, the stereotype of accountants as someone comically inept, dysfunctional misfits, occasionally criminally inclined, antisocial and a dowdy 'nerdishness' belongs to a past that no longer corresponds with the scope of accounting work being undertaken.

If communication skills were important in the past, what could we expect for the future? We are now living in the middle of the Fourth Industrial Revolution. It has many implications in the way organizations operate and the way people work. Millions of new jobs are being created; millions of jobs are disappearing; there are new challenges and new opportunities for fulfilling people's potential and aspirations. However, as stated in WEF (2020:4), "in order to turn these opportunities into reality, new sources of data and innovative approaches to understanding emerging jobs and skills, as well as to empower effective and coordinated large-scale action are urgently needed across the globe." The digitalization of the economy and society brings new issues to the labor market (Tverdushka \& Stoliaruk, 2020). The development of automation enabled by technologies such as Artificial Intelligence (Al), Internet of Things (IOT), Cloud, Robotics, Blockchain and so on promises a future of greater productivity, efficiency, and security. But this technological disruption also raises difficult questions across labour markets, namely on 
the necessary skills for the existing professions. The professions related to management and accounting are one of those cases. Indeed, many activities that Accountants perform today are susceptible to automation, so it seems clear that the new era of automation will require accounts professionals a range of new skills in the workplace, from technological knowledge to essential social and emotional capabilities. Thus, any serious debate of the future of the accounting profession must be headed by a clarification of what the profession and also by the definition of which are the skills necessary to succeed in the current changing working environment".

In this context, "there seems to be a higher importance placed on communications skills" (Arquero et al, 2015:14). Actually, "adding to a large and growing body of research, recent international studies demonstrate how consistently communication skills are regarded as being essential to professional success in accounting" (Gray and Hamilton, 2014:115). And thus, communication apprehension represents a real problem for the accounting student, during his/her academic life, and for the accounting profession, if he/she wants to succeed in the competitive world of 21 st century.

Communication apprehension is an individual emotional reaction of worry, anxiety or panic connected with any situation of communication with another person or persons. In the relational world, we can all have conscious feelings of reverence, embarrassment, shyness, and shame in the face of strangers, or reservation and discretion when third parties are involved. In the genesis of these reactions, they could be positive and wellaware defence mechanisms like conservation of life or avoidance of danger but is can also mean emotional problems. Psychology, biology, psychiatry highlights different, but also complementary explanations for these reactions. Of course, biology explains very well the reactions observed in a moment of stress, by the action of the vegetative system that equips the sympathetic / parasympathetic. The effects are known (heart acceleration, flushing, dry mouth, sweats). Science knows the neurotransmitters involved and much more. But the real cause of this sudden suffering may be emotional. Therefore, the apprehension during a public presentation or other communication situation can partly be due to a natural fear and the mob's realistic reaction or it can be due to emotional problems.

After the call for educational research projects dealing with enhancing thinking and communication skills within accounting education, launched by Nikolai (1996), many studies related with communication apprehension emerged in this area. Prior work of Andrews, and Koester (1979) had already identified communication difficulties felt by recently graduated accountants. The authors (1979:42) concluded that "accounting educators and accounting professionals are in general agreement about the communication needs of accountants but ... there was some disagreement about how to achieve the necessary skill levels".

Other study conducted by Simons, Higgins and Lowe (1995:159), revealed that "accounting majors have higher apprehension toward both written and oral communications than other business majors", while "gender differences were found only for oral communication apprehension, with female accounting majors reporting the highest apprehension. The implications of these findings are discussed". Recognizing that "the level of an individual's anxiety toward written and oral communication may be an obstacle to improving the related skills and may require different forms of curriculum content and pedagogy" (Simons, Higgins, \& Lowe, 1995:170), the authors advise accounting teachers professors to follow behavioral and pedagogical approaches to reducing communication apprehension.

Smythe and Nikolai (2002) applied a three-dimensional "communication concerns model": (1) concerns about self, (2) concerns about task, and (3) concerns about impact, to a sample of three different accounting constituencies: undergraduate accounting 
majors, accounting graduate students, and professional accountants. Based on the identification of themes of oral communication concerns that arise from the study, the authors make suggestions for the content and sequencing of oral communication instruction in collegiate or post-collegiate instruction, namely "accounting education programs need to expand the number of oral communication training opportunities for students, as well as the range of communication skills covered in existing course work. However, it is difficult to incorporate entirely new course requirements into already crowded accounting programs, and many accounting educators are wary of replacing accounting theory/practice courses with oral communication skill-oriented course work. ... the most basic issues, such as oral communication apprehension, public speaking instruction, and the processes of audience adaptation, should be introduced early in the undergraduate experience. However, oral communication skill development requires continued exposure and practice. Instruction in more advanced communication skills needs to follow later in the sequence" (Smythe \& Nikolai, 2002:176-177).

From Turkish Universities, Geçer and Gümüş (2010:3013) reported that "that private university students have lower levels of communication apprehension with lecturers" and "students at faculties of education and medicine have higher levels of apprehension". The authors justify it by the fact that "... at private universities, the communication between lecturers and students is normally monitored and duties such as providing new opportunities of communication and encouraging the students for communication are attached to the lecturers" (Geçer \& Gümüş, 2010:3013).

Presuming that accountants work in an increasingly changing, complex, and demanding environment, Hassall et al (2013) investigated accounting undergraduate students at a UK university. They suggested a link between communication apprehension and communication self-efficacy. According to the authors, findings confirm the connection between the two constructs. However, "whilst results indicated most differences in student learning patterns between Asian and European students, many differences were identified between students from the two Asian countries" (Hassall et al, 2013:169).

Coetzee, Schmulian and Kotze (2014) identified socio-economic differences in South African accounting students regarding communication apprehension. The authors reported significant differences "in communication apprehension between students from previously disadvantaged African communities attending poorly resourced schools, and African and White students attending well-resourced, Westernized schools.

Siriwardane and Durden (2014) reviewed 19 studies published between 1972 and 2012 concerning communication skills of practicing accountants and expressed the concern about the fact that much of the existing communication skills research was crucially out of date, with only three research papers published during 2000-2012. In spited of the academic and professional research that has been published since then, "recent calls for more communication studies in accounting emphasize the need for this research to be more context-specific" (Siriwardane, Low, \& Blietz, 2015:333).

Arquero et al. (2015) explored the relationships between communication apprehension (CA), ambiguity tolerance (AT) and learning styles in accounting students and concluded that "high CA students tend to be less independent, more avoidant, less collaborative and less participant. AT appears to be negatively correlated with CA and dependent style. All of these are characteristics that are associated with constraints for the inclusion of active pedagogy and, analysed in conjunction with reported profiles of accounting students in these relevant characteristics, suggest that some accounting students tend to fail in more than one at the same time" (Arquero et al., 2015:20).

Siriwardane, Low and Blietz (2015) studied the specific communication skills and attributes of Entry-Level Accountants from Singapore. The authors concluded that: a) ELAs are 
engaged in written communication tasks more frequently than in oral communication tasks; b) Listening-related skills are the most important communication skills; c) Even though ELAs perform written communication tasks more frequently than oral communication tasks, oral communication skills top the (perceived) importance list; d)Informal speaking tasks are performed frequently, and no less frequently than formal presentations; e) Formal writing tasks (in various forms) are the least frequently performed; however, the difference between the importance ratings of formal and informal writing skills is statistically insignificant. f) The most important attribute of speaking, as well as writing, is clarity; g) The largest importance-performance gaps exist in the five most important skills: listening responsiveness and attentiveness, reading comprehension, paraphrasing, and formal writing.

\section{METHODOLOGY}

This is a quantitative study on Oral Communication Apprehension (OCA), which collected data through an online questionnaire made available in June 2020, from the Personal Report of Communication Apprehension (PRCA) (McCroskey et al., 1985). The data were processed by using IBM and SPSS 27, being applied several statistical tests of validity and reliability.

This article aims to analyze the perception of OCA abilities among students of accounting courses in Portuguese public Higher Education Institutions (HEls), so we evaluated the levels of oral communication apprehension of students from thirteen institutions that offer accounting graduate courses, i.e., the all entire population under study, in order to identify the global prevalence of the problem and the differences between institutions, gender, age and academic year.

\subsection{Sample and its characterization}

The target population of the study are students of accounting graduate courses in Portugal, in June 2020 (corresponding to the academic year 2019/20). From the total of 2,343 students, it was obtained 879 responses to the questionnaire, but only 813 were considered valid (which presents a representativeness rate of $34.7 \%$ ), which constitutes our sample, which is equivalent to a response rate of $92.5 \%$.

The sample included thirteen public Higher Education Institutions (twelve Polytechnics and one University), which represents $93 \%$ of the country's total institutions, the distribution of respondents is shown in Table 1.

The characterization of the sample is made by gender, age, academic year of enrolment, in the academic year 2019/20.

As regards to gender, it is mostly female (with 62\% reaching higher rates in ISCA Porto, IP Cávado e Ave, IP Setúbal and ISCA Lisboa) and, therefore, the other $38 \%$ are male, as shown in Table 1.

Regarding to age, there is an average of 18.5 years, a variance of 36.7 years and the age of the youngest and oldest student is 17 and 63 years old, respectively.

The students under the study were divided in four groups, according to the age group: under 23 years old (which corresponds to students coming from the general regime of access to higher education), between 23 and 30 years old, from 31 to 40 years old and more than 40 years old (which usually corresponds to a special regime, called the competition for those over 23 years old).

We also found that in all HEls, the majority of students are in the age group for students under 23 (with IP Santarém and IP Viana do Castelo reaching 100\%), nine institutions have around $86 \%$ of their students aged between 17 and 30 and only four institutions (ISCA 
Porto, IP Cávado e Ave, IP Setúbal and ISCA Aveiro) have the highest values in the age group over 31 (31 to 40 and over 40), with 33, 24, 17 and 17 students, respectively, which represents about $14 \%$ of the sample.

Table 1. Distribution of Students Responding to the Questionnaire, by Institution and gender

\begin{tabular}{l|rrrrrrrr} 
& Sample & \multicolumn{2}{c}{$\begin{array}{c}\text { Male } \\
\text { \% Total } \\
\text { of Male }\end{array}$} & $\begin{array}{l}\text { \% Total of } \\
\text { sample }\end{array}$ & $\begin{array}{l}\text { Female } \\
\text { Female }\end{array}$ & $\begin{array}{l}\text { Total ofal of } \\
\text { sample }\end{array}$ \\
\hline IP Bragança & 19 & $2,3 \%$ & 7 & $2,3 \%$ & $0,9 \%$ & 12 & $2,4 \%$ & $1,5 \%$ \\
IP Cávado e Ave & 113 & $13,9 \%$ & 32 & $10,3 \%$ & $3,9 \%$ & 81 & $16,1 \%$ & $10,0 \%$ \\
IP Leiria & 44 & $5,4 \%$ & 17 & $5,5 \%$ & $2,1 \%$ & 27 & $5,4 \%$ & $3,3 \%$ \\
IP Santarém & 14 & $1,7 \%$ & 5 & $1,6 \%$ & $0,6 \%$ & 9 & $1,8 \%$ & $1,1 \%$ \\
IP Setúbal & 105 & $12,9 \%$ & 41 & $13,2 \%$ & $5,0 \%$ & 64 & $12,7 \%$ & $7,9 \%$ \\
IP Tomar & 6 & $0,7 \%$ & 2 & $0,6 \%$ & $0,2 \%$ & 4 & $0,8 \%$ & $0,5 \%$ \\
IP Viana do Castelo & 11 & $1,4 \%$ & 4 & $1,3 \%$ & $0,5 \%$ & 7 & $1,4 \%$ & $0,9 \%$ \\
IP Viseu & 19 & $2,3 \%$ & 7 & $2,3 \%$ & $0,9 \%$ & 12 & $2,4 \%$ & $1,5 \%$ \\
ISCA Aveiro & 73 & $9,0 \%$ & 29 & $9,4 \%$ & $3,6 \%$ & 44 & $8,7 \%$ & $5,4 \%$ \\
ISCA Coimbra & 44 & $5,4 \%$ & 16 & $5,2 \%$ & $2,0 \%$ & 28 & $5,6 \%$ & $3,4 \%$ \\
ISCA Lisboa & 108 & $13,3 \%$ & 48 & $15,5 \%$ & $5,9 \%$ & 60 & $11,9 \%$ & $7,4 \%$ \\
ISCA Porto & 196 & $24,1 \%$ & 82 & $26,5 \%$ & $10,1 \%$ & 114 & $22,7 \%$ & $14,0 \%$ \\
U Minho & 61 & $7,5 \%$ & 20 & $6,5 \%$ & $2,5 \%$ & 41 & $8,2 \%$ & $5,0 \%$ \\
\hline Total & $\mathbf{8 1 3}$ & $\mathbf{1 0 0 , 0 \%}$ & $\mathbf{3 1 0}$ & $\mathbf{1 0 0 , 0 \%}$ & $\mathbf{3 8 , 1 \%}$ & $\mathbf{5 0 3}$ & $\mathbf{1 0 0 , 0 \%}$ & $\mathbf{6 1 , 9 \%}$ \\
\hline
\end{tabular}

Finally, students were divided according to their academic year, which resulted in 269 (33\%), 216 (27\%) and 328 (40\%) students enrolled in 1st, 2nd and 3rd years, respectively.

The institutions with the largest number of students enrolled in the 1st year are ISCA Lisboa and ISCA Porto (with 62 and 53, respectively, which represents 14\%), enrolled in the 2nd year are ISCA Porto and IP Setúbal (with 54 and 48, respectively, which corresponds to $13 \%$ ) and enrolled in the 3rd and last year, are IP Cávado e Ave and ISCA Porto (both with 89 , which represents $22 \%$ ).

\subsection{Measuring instruments}

To collect the data, a questionnaire was used, composed of two parts: the first with sociodemographic and academic variables and the second with the constructs of the model under analysis.

The questionnaire was translated from English to Portuguese and specialists verified the reliability and validity of the OCA content in psychology and accounting fields to ensure that the items on the original scale maintained the base structure and could be adapted to accounting students before being applied at the end of the second semester of 2019/20, after the teachers authorized each of the HEls.

Appendix 1 presents the four analyzed constructs (Public Speaking, Meetings, Group Talking and Oral Presentations), with a total of 24 questions, which were measured using the Likert-type scale (from 1 to 5), ranging from "Totally Agree" to "Totally Disagree". 


\subsection{Validity and Reliability of PRCA}

To assess the validity of the obtained results from the PRCA scale application, we carried out an Exploratory Factorial Analysis (EFA) (Yong, Pearce, \& others, 2013) that allowed us to obtain statistical evidence of data quality and capacity of measuring the PRCA scale in accounting students. We used the Principal Components Method (PCM) with oblique rotation to extract the factors with values $\geq 1$, which resulted in a $\mathrm{KMO}=0.941$. We obtained 4 factors that explained $64.639 \%$ of the PRCA variance (Table 2).

Table 2. EFA: Total Variance Explained

Initial Eigenvalues

Extraction Sums of Squared Loadings

\begin{tabular}{lllllll}
\cline { 2 - 6 } Component & Total & \% of Variance & Cumulative \% & Total & \% of Variance & Cumulative \% \\
\hline $\mathbf{1}$ & 10.731 & 44.713 & 44.713 & 10.731 & 44.713 & 44.713 \\
\hline $\mathbf{2}$ & 2.092 & 8.719 & 53.432 & 2.092 & 8.719 & 53.432 \\
\hline $\mathbf{3}$ & 1.474 & 6.143 & 59.575 & 1.474 & 6.143 & 59.575 \\
\hline $\mathbf{4}$ & 1.215 & 5.064 & 64.639 & 1.215 & 5.064 & 64.639 \\
\hline
\end{tabular}

Extraction Method: Principal Component Analysis.

We can see the exploratory factorial matrix of the 24 items of the PRCA and their respective factor loads, where we can see how the variables were distributed by the four factors resulting from the EFA. Also, the Cronbach's Alpha value for the 24 items of the scale presented results that evidenced its robustness, standing at 0.918 to PCRA (Appendix 2).

The four factors obtained, all with loads higher than 0.5, are conceptually the most indicated in communication apprehension and written apprehension contexts. To test the reliability of each of the individual scales, we extracted the Cronbach Alpha. All the constructs obtained the Cronbach Alpha $>0,9$, i.e., all exceeding the acceptable level of 0.7 (Taber, 2018).

\section{RESULTS}

\subsection{Higher Education Institutions}

The results analysis is divided into four points: the first, by HEls, the second, by gender, the third, by age and the last and fourth point, by academic year.

As regards the first point, results by HEls, we found that there are seven institutions above the average and the remaining six are below the sample average, as can be seen in Table 3, the result 63.983 is considered in the literature on this topic as an average and all the institutions surveyed are included in this qualification of average.

There are seven HEls with values above the average of the Total OCA (ISCA Porto, IP Cávado e Ave, ISCA Aveiro, IP Setúbal, U Minho, IP Santarém and ISCA Lisboa) those institutions not only have more students, but we also obtained more responses to the questionnaire, except for IP Cávado e Ave, IP Santarém and ISCA Coimbra. Consequently, those with values below the sample average are six (ISCA Coimbra, IP Viseu, IP Bragança, IP Leiria and IP Tomar) with a smaller number of students and responses.

An identical conclusion is reached in any of the four constructs of oral communication apprehension, except for IP Viseu, in the meeting construct, which is slightly higher than the total average of the HEls. The institution with the lowest result in all constructs was IP 
Tomar (with 53.000 of Total OCA), and it is the one with the lowest number of enrolled students.

Table 3. Results from Communication Apprehension Oral Constructs by HEl

\section{Communication Apprehension Constructs}

\begin{tabular}{lrrrrr} 
& Public Speaking & Meetings & Group Talking & Oral Presentations & Total CA \\
\hline IP Bragança & 14,684 & 13,947 & 16,474 & 15,053 & 60,158 \\
IP Cávado e Ave & 17,425 & 16,805 & 19,540 & 16,106 & 69,876 \\
IP Leiria & 14,227 & 13,023 & 13,023 & 14,318 & 57,295 \\
IP Santarém & 17,714 & 16,071 & 18,500 & 15,429 & 67,714 \\
IP Setúbal & 16,505 & 16,390 & 18,257 & 16,952 & 68,105 \\
IP Tomar & 12,500 & 12,667 & 14,500 & 13,333 & 53,000 \\
IP Viana do Castelo & 15,000 & 12,727 & 16,091 & 14,909 & 58,727 \\
IP Viseu & 15,684 & 15,579 & 17,053 & 15,000 & 63,316 \\
ISC Aveiro & 16,466 & 16,041 & 18,699 & 17,041 & 68,247 \\
ISCA Coimbra & 15,795 & 15,068 & 17,386 & 15,114 & 63,364 \\
ISCA Lisboa & 16,561 & 15,963 & 18,374 & 16,000 & 66,897 \\
ISCA Porto & 17,566 & 16,352 & 19,245 & 16,847 & $\mathbf{7 0 , 0 1 0}$ \\
U Minho & 16,459 & 16,016 & 18,902 & 16,393 & 67,770 \\
\hline Total HEI & $\mathbf{1 5 , 8 9 1}$ & $\mathbf{1 5 , 1 2 7}$ & $\mathbf{1 7 , 3 8 8}$ & $\mathbf{1 5 , 5 7 7}$ & $\mathbf{6 3 , 9 8 3}$
\end{tabular}

Key: Level of CA: High (>80); Average (50 to 80); Low (<50).

\subsection{Gender}

Regarding gender, Total OCA results are average, both for men and women, with men always standing above the average in all constructs (about 3.284 points), which means that they assume they have more difficulties in oral expression than the female gender, which is always below the average, equally, in all constructs (about -1.338 points), as shown in Table 4.

Table 4. OCA Results by Gender

\begin{tabular}{lrrrrrr} 
& \multicolumn{6}{c}{ Communication Apprehension Constructs } \\
& $\begin{array}{l}\text { Public } \\
\text { Speaking }\end{array}$ & Meetings & $\begin{array}{l}\text { Group } \\
\text { Talking }\end{array}$ & $\begin{array}{l}\text { Oral } \\
\text { Presentations }\end{array}$ & Total CA \\
\hline Male & 16,163 & 15,990 & 18,017 & 17,098 & $67,267^{*}$ \\
Female & 15,765 & 14,647 & 17,371 & 14,862 & $62,645^{*}$ \\
\hline Total & $\mathbf{1 5 , 8 9 1}$ & $\mathbf{1 5 , 1 2 7}$ & $\mathbf{1 7 , 3 8 8}$ & $\mathbf{1 5 , 5 7 7}$ & $\mathbf{6 3 , 9 8 3}$ \\
\hline
\end{tabular}

Key: Level of CA: High (>80); Average (50 to 80); Low (<50); * t-test sig. $p<0.05$

The achieved results are consistent in any of the four constructs by gender type, with both male and female having more difficulties in the construct - Oral Presentations - with 1.521 and 0.714 points higher than the general sample average, respectively.

To verify if the differences observed in the total results of oral communication apprehension were statistically significant, we performed an inferential analysis using ${ }^{\dagger}-$ test for the variable total CA and for the factors of gender. In Table 5, we can observe 
the variables for gender. Both the gender lines allow us to visualize the effects of these variables on the total CA. As $p<0.05$ we can see Communication Apprehension differences between gender.

Table 5. OCA Results by Gender: Differences between means

\begin{tabular}{llcccc} 
& Gender & N & Mean & Std. Deviation & Std. Error Mean \\
\hline OverallCA & Male & 310 & $67,267^{*}$ & 17,338 &, 984 \\
& Female & 502 & $62,645^{*}$ & 17,866 &, 797 \\
\hline
\end{tabular}

Note: Levene's test for Equality of Variances shows, with $95 \%$ confidence interval, equal variances assumed between two groups.

We find that there are statistically significant differences in Total CA between male and female students. Male students have a higher oral apprehension (67.267) than female students (62.645). This is also true for all the subdimensions of oral comprehension like Public Speaking (Male: 16.163 vs Female: 15.765), Meetings (Male: 15.990 vs Female: 14.647), Group Talking (Male: 18.017 vs Female: 17.371) and Oral Presentations (Male: 17.098 vs Female: 14.862). This shows that male students have more difficulties in CA, in all its dimensions, than female students, as we can see in Table 5 above.

\subsection{Higher Education Institutions vs Gender}

When crossing the results, Higher Education Institution and gender, we obtained several evidences, the synthesis of which is shown in Appendix $N^{\circ} 1$. There are six institutions in the female gender (IP Cávado e Ave, ISCA Lisboa, ISCA Porto, IP Santarém, ISCA Aveiro and IP Setúbal) that are clearly above average (between 3.043 and 8.541 points), against the seven remaining, which are between -1.811 and -18.145 . The higher results reveal that female students from the first group of institutions have a clear perception of their oral difficulties, to the detriment of students from the second group, highlighting the result of IP Tomar (with 44.500 points), which is the only institution with an average considered low.

There are eight institutions in the male gender (IP Setúbal, ISCA Porto, ISCA Aveiro, IP Tomar, IP Santarém, ISCA Coimbra, U Minho e IP Viseu) that are clearly above average (between 0.304 and 4.613 points) where students recognize their difficulties in speaking, against the remaining five institutions, which are between -0.707 and -5.517 below the average of this gender. All results are classified as average in terms of oral difficulties.

When comparing the obtained results by gender in the institutions, we found an identical recognition of the difficulties in oral expression in three institutions (IP Bragança, IP Leiria and IP Viana do Castelo), where male gender says to feel more difficulties than his counterpart in five institutions (IP Setúbal, IP Viseu, ISCA Aveiro, ISCA Coimbra and U Minho), and that female gender thinks to have more difficulties than its counterpart in four institutions (IP Cávado e Ave, IP Tomar, ISCA Lisboa and ISCA Porto).

The differences between institutions are related to several factors, such as sociodemographic (gender and age) as well as socio-cultural (family background) and social (students' origin, area of the country they live in, and economic class to which they belong). 


\subsection{Age}

As for the third point, the results by age or age group, by analysing Table 6, we can verify that the level of Total CA in the sample is considered average, and in the age group of above 40 years old students, Total CA is qualified as high, for being over 80 points.

Table 6. OCA Results by Age

\begin{tabular}{|c|c|c|c|c|c|c|}
\hline \multirow[t]{2}{*}{ Age } & \multirow[b]{2}{*}{ Sample } & \multicolumn{5}{|c|}{ Communication Apprehension Constructs } \\
\hline & & $\begin{array}{l}\text { Public } \\
\text { Speaking }\end{array}$ & Meetings & $\begin{array}{l}\text { Group } \\
\text { Talking }\end{array}$ & $\begin{array}{l}\text { Oral } \\
\text { Presentations }\end{array}$ & Total CA \\
\hline$<23$ years & 571 & 15,207 & 14,498 & 17,087 & 15,109 & $61,900^{*}$ \\
\hline $23-30$ years & 131 & 15,824 & 15,470 & 17,918 & 16,389 & $65,601^{*}$ \\
\hline $31-40$ years & 56 & 19,513 & 18,034 & 19,860 & 18,232 & $75,639^{*}$ \\
\hline$>40$ years & 55 & 20,342 & 19,806 & 21,696 & 19,965 & $81,810^{*}$ \\
\hline Total Sample & 813 & 15,891 & 15,127 & 17,388 & 15,577 & 63,983 \\
\hline
\end{tabular}

Note: See Tests of Between-Subjects Effects in Appendix 3

Key: Level of CA: High (>80); Average (50 to 80); Low (<50); ANOVA test sig. $p<0.05$

There are significant differences in the Total CA results between students age group "less than 23 years old" an age groups "31-40 years old" and ">40 years old", which differences reach 13.739 and 19.909 points, that correspond to more than $22 \%$ and $32 \%$, respectively.

Thus, the greater the age, the recognition by the students in the sample of their difficulties in oral communication is greater, in all constructs, with the most expressive differences in the Meetings and Public Speaking constructs where only students with "less than 23 years old" are always positioned with values below the average of the sample in the various constructs under consideration.

To verify if the difference observed in the total results of Oral Communication Apprehension was statistically significant, we performed an inferential analysis through ANOVA for the variable Total CA and the factor Age. In Appendix 3 we can observe the variable Age to visualize the effect of these variable on Total CA. As $p<0.05$ for both, we can see that age influenced Overall CA and we have differences between groups.

\subsection{Higher Education Institutions vs Age}

In a longitudinal analysis, we found that the results of the age group by educational institution are not always homogeneous, as shown in Table 7 and in Annex $N^{\circ} 2$.

In this sense, students of IP Bragança, IP Tomar and IP Viana do Castelo are always positioned with values below the average of CA, with the most expressive values, in the case of IP Bragança with -13.851 points in the age group of "23-30 years old" and the IP Tomar with -11.544 points in the "<23 years old" age group. In turn, students of IP Santarém present values above the CA average, in the age group of "<23 years old", with +4.916 points. ISCA Aveiro and ISCA Lisboa students present values above the CA average in the "<23 years old" and "23 - 30 years old" age groups and below the CA average in the other age groups "31 - 40 years old" and "> 40 years old". IP Cávado e Ave and ISCA Porto students present values above the CA average in the "<23 years", "23 - 30 years" and "31 - 40 years" age groups and below the CA average in the other age groups "> 40 years". IP Setúbal students are slightly different from the previous ones, they present values above the CA average in the "<23 years", "23 - 30 years" and "> 40 years" age groups and below the CA average in the age groups "31 - 40 years". Finally, students from U Minho 
demonstrate a value above the CA average in the "> 40 years" age groups and below the CA average in the "<23 years" and "23 - 30 years" age groups.

Table 7. Difference between the Total CA of the Higher Education Institution (HEI) and the Sample Average of Age

\begin{tabular}{|c|c|c|c|c|c|c|c|c|}
\hline \multirow[b]{2}{*}{ HEI \Age } & \multicolumn{4}{|c|}{$\begin{array}{l}\text { Difference between the Total CA of } \\
\text { the Higher Education Institution (HEI) } \\
\text { and the Sample Average, when the } \\
\text { HEI result is lower than the sample }\end{array}$} & \multicolumn{4}{|c|}{$\begin{array}{l}\text { Difference between the Total AC } \\
\text { of the Higher Education Institution } \\
\text { (HEI) and the Sample Average, } \\
\text { when the HEI result is higher than } \\
\text { the sample }\end{array}$} \\
\hline & $<23 a$ & $23-30$ & $31-40$ & $>40$ & $<23 a$ & $23-30$ & $31-40$ & $>\mathbf{4 0}$ \\
\hline IP Bragança & $-0,394$ & $-13,851$ & na & na & - & - & na & na \\
\hline IP Cávado e Ave & - & - & - & $-5,810$ & 2,446 & 8,166 & 1,028 & - \\
\hline IP Leiria & $-7,084$ & $-11,768$ & - & na & - & - & 7,028 & na \\
\hline IP Santarém & - & na & na & na & 4,916 & na & na & na \\
\hline IP Setúbal & - & - & $-0,639$ & - & 1,776 & 5,566 & - & 0,008 \\
\hline IP Tomar & $-11,544$ & $-9,101$ & na & na & - & - & na & na \\
\hline IP Viana do Castelo & $-4,064$ & na & na & na & - & na & na & na \\
\hline IP Viseu & - & $-6,601$ & na & na & 1,676 & - & na & na \\
\hline ISCA Aveiro & - & - & $-4,139$ & $-11,810$ & 2,536 & 8,185 & - & - \\
\hline ISCA Lisboa & - & - & $-2,972$ & $-8,210$ & 1,656 & 13,853 & - & - \\
\hline ISCA Coimbra & $-0,294$ & $-2,934$ & na & - & - & na & na & 18,190 \\
\hline ISCA Porto & - & - & - & $-4,060$ & 4,816 & 3,487 & 8,669 & na \\
\hline U Minho & - & - & $-8,973$ & - & 3,756 & 4,999 & - & 11,690 \\
\hline
\end{tabular}

\subsection{Curricular year}

The results by curricular year show that every year presents a value considered as average by the literature, although the 1st curricular year presents the lowest value, 1st year students say they feel less difficulties in oral communication, as shown in Table 7.

However, as students' progress in their curricular years, they show more difficulties in speaking, which may mean that as they attend the following years and gain more skills, they become more aware of their difficulties in oral communication.

As an example, the difference in the CA average between the 3rd year and the 1st year is 8.408 points, which is equivalent to an additional $14 \%$, while the difference in the CA average between the 3rd year and the 1st year is 2.793 points, which corresponds to more than $5 \%$.

The difference between the 1st academic year and the following is common in all constructs. However, it is more significant in the Meeting and Oral Presentations, with more 2.439 and 2.470 points in the 3rd academic year compared to the 1st academic year, respectively. The biggest difference between the 2nd and 1st curricular years is observed in the Group Talking, with more 0.814 points.

To verify if the differences observed in the total results of oral communication apprehension were statistically significant, we performed an inferential analysis using $t-$ test for the variable total CA and for the factor curricular year. In Table 9 and 10, we can observe the variables for gender. Both the gender lines allow us to visualize the effects of 
these variables on the total CA. As $p<0.05$ we can see Communication Apprehension differences between gender.

Table 8. OCA Results by Curricular Year

\begin{tabular}{llllll}
\hline Curricular Year & \multicolumn{5}{c}{ Communication Apprehension Constructs } \\
\cline { 2 - 6 } & $\begin{array}{l}\text { Public } \\
\text { Speaking }\end{array}$ & Meetings & $\begin{array}{l}\text { Group } \\
\text { Talking }\end{array}$ & $\begin{array}{l}\text { Oral } \\
\text { Presentations }\end{array}$ & Total CA \\
\hline $\mathbf{1}^{\text {st }}$ Year & 15,313 & 14,452 & 16,972 & 14,914 & $61,651^{*}$ \\
$2^{\text {nd }}$ Year & 15,958 & 14,996 & 17,786 & 15,395 & $64,444^{*}$ \\
$3^{\text {rd }}$ Year & 17,082 & 16,892 & 18,703 & 17,384 & $70,059^{*}$ \\
\hline Total Sample & $\mathbf{1 5 , 8 9 1}$ & $\mathbf{1 5 , 1 2 7}$ & $\mathbf{1 7 , 3 8 8}$ & $\mathbf{1 5 , 5 7 7}$ & $\mathbf{6 3 , 9 8 3 ^ { * }}$ \\
\hline
\end{tabular}

Key: Level of CA: High (>80); Average (50 to 80); Low (<50); * $\mathrm{p}<0.05$

\subsection{Higher Education Institutions vs Age}

In a longitudinal analysis by $\mathrm{HEl}$ and curricular year, it can be concluded from Table 8 that there are four institutions (IP Setúbal, ISCA Aveiro, ISCA Lisbon and ISCA Porto) whose Total OC values are always higher than the curricular year average, in any of the three curricular years, which means that these students always experience oral difficulties, regardless of the year they attend, which we believe may be more associated with their personal profile or DNA. In the previous point, on the opposite, we can verify that there are three institutions (IP Leiria, IP Viana do Castelo and ISCA Coimbra) whose Total OC values are always lower than the curricular year average, in any of the three curricular years, we can see that these values are lower from year to year, which may mean that students are becoming aware of their oral limitations.

Table 8. Difference between the Total CA of the Higher Education Institution (HEI) and the Sample Average of Curricular Year

Difference between the Total CA of Difference between the Total CA of HEI \Curricular Year the Higher Education Institution (HEI) the Higher Education Institution (HEI) and the Sample Average, when the and the Sample Average, when the

\begin{tabular}{|c|c|c|c|c|c|c|}
\hline \multirow{2}{*}{ Curricular Year } & \multicolumn{3}{|c|}{ HEI result is lower than the sample } & \multicolumn{3}{|c|}{ HEI result is higher than the sample } \\
\hline & $1^{\circ}$ Year & $2^{\circ}$ Year & $3^{\circ}$ Year & $1^{\circ}$ Year & $2^{\circ}$ Year & $3^{\circ}$ Year \\
\hline IP Bragança & - & $-12,005$ & $-8,913$ & 7,059 & - & - \\
\hline IP Cávado e Ave & $-3,495$ & - & - & - & 6,919 & 1,570 \\
\hline IP Leiria & $-10,568$ & $-4,172$ & $-4,313$ & - & - & \\
\hline IP Santarém & - & $-1,772$ & - & 3,993 & - & 11,420 \\
\hline IP Setúbal & - & - & - & 4,347 & 3,536 & 2,047 \\
\hline IP Tomar & $-12,941$ & - & - & - & - & 6,087 \\
\hline IP Viana do Castelo & $-7,507$ & $-7,172$ & $-0,246$ & - & - & \\
\hline IP Viseu & - & $-4,172$ & $-9,342$ & 6,034 & - & \\
\hline ISCA Aveiro & - & - & - & 0,459 & 5,966 & 3,929 \\
\hline ISCA Lisboa & - & - & - & 3,574 & 4,128 & 0,472 \\
\hline ISCA Coimbra & $-3,653$ & $-0,272$ & $-1,802$ & - & - & - \\
\hline ISCA Porto & - & - & - & 8,414 & 2,087 & 2,525 \\
\hline U Minho & - & - & $-3,433$ & 4,284 & 6,928 & - \\
\hline OCA Average & 61,341 & 64,172 & 69,913 & 61,341 & 64,172 & 69,913 \\
\hline
\end{tabular}

There are two institutions (IP Bragança and IP Viseu) that in the 1st curricular year present much higher values than the OC average of that year and in the following curricular years, present much lower values than the OC average of the 2nd and 3rd curricular years, which means that in the 1st year students recognize their oral weaknesses, which 
decrease considerably as they move on to the following years. The U Minho is positioned in a very similar way, where we can see values above the OC average in the following 1 st and 2 nd curricular years and more reduced compared to the OC average in the 3rd year. Finally, the IP Cávado e Ave and IP Tomar have OC values in the 1st curricular year below the respective general average, while the $\mathrm{OC}$ values in the 2 nd and 3 rd curricular years are higher than the average.

\subsection{Discussion}

The most relevant results of the study are the description of the number of responses according to the geographic location of the school, the age, sex and school year of the student, both for the sub-scales that contextualize the anxious response, and for the global score that results from the sum of the sub-scales. However, although the number of responses considered null is acceptable (less than 10\% of the completed forms), it appears that the number of forms obtained represents a modest percentage $(34.7 \%)$ of the universe of expected students. It raises several questions for the authors, one of which is related to the type of methodology used. It is a known fact that a high percentage of people avoid filling out so-called online surveys, either for fear of an invasion of their privacy or for understandable fear of being a victim of computer scams. We all know that there never was and there is no absolute personal security when using computers.

However, the percentage of responses obtained in the national territory may also be affected by the essence of the subject under study. Because suffering from apprehension when speaking can be a sufficient reason for the person to adopt an escape attitude (refusing to answer) in the face of simply evoking this problem. However, it will also be permissible to think the opposite, that some people with the problem are especially interested in such a study because it proposes to address a subject that concerns them so much. There will therefore be a possibility that the sample of students obtained corresponds to a "sample of volunteers" individuals who are superiorly interested and collaborating. Such uncertainty limits, to some extent, the conclusions to be drawn from the study.

In addition, as shown in Table 1, the absolute number of responses obtained has very different values depending on the geographic region in which the school is located. And, although the table does not include the base population (the total number of students in that school), in certain places this number of responses is residual (ex: in IP Tomar, only 6 completed forms were obtained, contrasting with IP Lisboa that provided the largest number of responses). Therefore, in future studies, it would be advisable to outline a strategy that would allow to overcome such a low representativeness of the sample and, in the present case, the authors may, at a later stage, select a sample of the students who did not answer, preferably in one of the institutions where the percentage of responses is lower, to identify possible similarities and disparities between the sample of volunteers obtained and the population.

Another relevant issue is that the sample consists mainly of female members (62\%), which, despite everything, can reflect the fact that there is a national predominance of women studying accounting. As for the distribution of scores by age (table 2), the vast majority belong to very young students ( $<23$ years old).

Table 6 presents the overall results of the scores obtained in the different schools that participated in the study and it is concluded that the average of the values obtained for the apprehension in their different contexts (groups, meetings, interpersonal conversations, and public speaking), are generally within the expected range in populations considered to be at normal risk (scores <18). Furthermore, as would be expected, the same is true of the global scores, which always have values below 80 . 
However, and only in situations of public presentations, some schools exceed the threshold of normality, suggesting that there are many students, among those screened, especially male (table 7) who suffer from clinical apprehension. Another risk group isolated by the study is the 3rd year students (table 10), when they are faced with the need to speak in a group. But it is difficult to infer the reasons for the greatest risk in certain schools or in a given school year, based on the variables studied.

Along with the results discussed above, one of the most important questions that raises up is about the scores obtained and a pre-established threshold, i.e., from what total value the authors consider the student to have a real problem, and how often is the problem in the group of students who completed the questionnaire. Scores can range from a minimum of 24 to a maximum of 120. A higher score indicates a higher level of reported apprehension. For this study, the authors use the total CA score, instead of the means of each dimension. In table 10, we summarize the prevalence of CA within Higher Education Institution, considering the score $>80$ as the High Level of CA.

Table 10. Difference between the total CA score each of the Higher Education Institution (HEI) and the Sample Average of Curricular Year

\begin{tabular}{|c|c|c|c|c|}
\hline 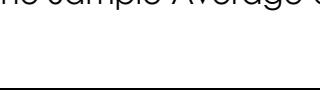 & $\begin{array}{l}\text { Number of } \\
\text { answers }\end{array}$ & valid & $\begin{array}{l}\text { Number of students } \\
\text { with } O C A>80\end{array}$ & $\begin{array}{l}\text { Prevalence of } \\
\text { OCA (\%) }\end{array}$ \\
\hline IP Bragança & 19 & & 2 & $11 \%$ \\
\hline IP Cávado e Ave & 113 & & 26 & $23 \%$ \\
\hline IP Leiria & 44 & & 4 & $9 \%$ \\
\hline IP Santarém & 14 & & 2 & $14 \%$ \\
\hline IP Setúbal & 105 & & 26 & $25 \%$ \\
\hline IP Tomar & 6 & & 0 & $0 \%$ \\
\hline IP Viana do Castelo & 11 & & 0 & $0 \%$ \\
\hline IP Viseu & 19 & & 1 & $5 \%$ \\
\hline ISCA Aveiro & 73 & & 13 & $18 \%$ \\
\hline ISCA Coimbra & 44 & & 9 & $20 \%$ \\
\hline ISCA Lisboa & 108 & & 19 & $18 \%$ \\
\hline ISCA Porto & 196 & & 48 & $24 \%$ \\
\hline UMinho & 61 & & 11 & $18 \%$ \\
\hline Total & 813 & & 161 & $20 \%$ \\
\hline
\end{tabular}

The first significant result from Table 10 is that in a total of 813 students analysed, 161 (20\%) showed high OCA scores. This result shows that although the general average data shows that OCA is within acceptable values $(50$ to 80 ) and far below the reference value that reveals high oral apprehension $(>80)$, this does not mean that there are no students who experience this OCA problem in higher education contexts.

If HEl makes the analysis, we can see that those where the response rate to the study was higher are also those where higher OCA values were found compared to the others. The four HEls where participation in the study was more relevant, with a higher number of responses, had OCA levels above 80 in more than $20 \%$ of their students surveyed. Our study reveals higher levels of prevalence of oral CA then those found by Tabassum and Hossain (2020) and by Gardner et al (2005). However, this last study was applied only to students in their final year of study in which they are exposed to greater communication demands.

The IP Setubal with a participation rate of 105 students presents 26 (25\%) with OCA>80 levels. ISCA Porto follows with a response rate of 196 students and $48(24 \%)$ with high OCA levels. In the third and fourth positions is IP Cávado e Ave with 26 students from the 113 who participated, revealing OCA levels around $23 \%$ of the total number of students and ISCA Coimbra with 9 students from the 44 who participated in the study presenting OCA levels of $20 \%$ of the total sample collected in this $\mathrm{HEl}$. The results of this study can help HEls to define more precise strategies to combat the OCA problems and, consequently, minimize its impact on students' academic performance. Furthermore, these results, when cross with the students' sociodemographic profile from 
each $\mathrm{HEl}$, can help to design very promising causality investigations for the study of OCA phenomenon. This is more relevant as there is evidence that great results have been obtained with single courses designed for accounting students that had reducing students' OCA as one of its main objectives (Ruchala \& Hill, 1994).

\section{Conclusion}

The $4^{\text {th }}$ Industrial Revolution is changing the accounting day to day working. Most technical accounting tasks and activities are being performed by robots and accountants are asked to develop their soft skills, namely communication skills, business presentation skills and other interpersonal skills. In today's challenging environment, oral communication skills remain crucial for academic and professional success.

This research explores the Oral Communication Apprehension of students. The main objective of this study was to characterize the epidemiological distribution of the subjective manifestations of anxiety in oral communications in the universe of accounting students who attended the various Portuguese academic institutions in June 2020. For this purpose, the authors of the study provided, on the internet, a Portuguese language version of a self-completion scale. Note that it was not intended to determine a national prevalence value of the problem, nor to identify the students who make up the fraction of people with the apprehension of significant value (those with an overall result> 80). As an alternative to such an approach, the authors preferred, in this phase of studying the problem of oral apprehension, to construct a generic map of the distribution, at the national level, of the availability of students to complete the questionnaire. The main findings of this study show that analysis of the OCA of all HEls at the same time and the analysis by HEl proves to be important as it expresses a more rigorous and particular panorama of the state of oral apprehension in which students find themselves, either in the broad set of HEls or by the institution. This information may be relevant concerning the need to promote teaching-learning methods capable of helping students combating this problem. It is also important to highlight that these policies are urgent because it is fundamental that the current accounting students and future professionals in this area are equipped with oral communication skills that allow them to enter, more efficiently, the demanding, competitive and globalised labour market.

The necessary transition process between learning in a higher education context and integration in the labour market is fundamental. The transfer of knowledge between university and industry harmoniously takes place and can make these professionals productive in the area in which they are professionally inserted.

A recommendation for future studies will therefore be the inclusion of other variables in the sociodemographic form; ex: number of household members, identification of other family cases with the problem, presence of family stress factors, number of previous failures, location of the current school and schools (coastal vs inland), schools where you carried out primary education and secondary, etc.

The main provisions and conclusions discussed in the article may be of interest to representatives of authorities at various levels, the scientific and expert community, representatives of the industrial and economic complex, as well as to find wide application in research and teaching practice. 


\section{REFERENCES}

American Accounting Association [AAA]. (1986). Committee on the Future Structure, Content, and Scope of Accounting Education [The Bedford Committee]: 'Future Accounting Education: Preparing for the Expanding Profession', Issues in Accounting Education (1): 168-195.

American Institute of Certified Public Accountants [AICPA]. (1999). The AICPA Core Competency Framework for Entry into the Accounting Profession. New York, NY: AICPA.

American Institute of Certified Public Accountants (AICPA) (2001). The AICPA core competency framework for entry into the accounting profession. Personal competencies. Available at: http://www.aicpa.org/edu/corecomp.htm.

Andrews, J. D. \& Koester, R. J. (1979). Communication difficulties as perceived by the accounting profession and professors of accounting, The Journal of Business Communication, 16(2), 33-33. https://doi.org/10.1177/002194367901600204

Arquero, J. L., Fernandez-Polvillo, C. F., Hassall, T., \& Joyce, J. (2017). Relationships between communication apprehension, ambiguity tolerance and learning styles in accounting students. Revista de Contabilidad-Spanish Accounting Review, 20(1), 13-24. https://doi.org/10.1016/j.rcsar.2015.10.002

Bills, D. B. (2016). 10. Education and Development. The sociology of development handbook, edited by Gregory Hooks, Berkeley: University of California Press, 241-262. https://doi.org/10.1525/9780520963474-012

Bloom, R., \& Myring, M. (2008). Charting the future of the accounting profession. CPA Journal, 78(6), 65-67. http://www.nysscpa.org/cpajournal

Burgoon, J. K., \& Hale, J. L. (1983). A research note on the dimensions of communication reticence. Communication $\quad$ Quarterly, $31(3), \quad 238-248$. https://doi.org/10.1080/01463378309369510

Coetzee, S. A., Schmulian, A., \& Kotze, L. (2014). Communication apprehension of South African accounting students: The effect of culture and language. Issues in Accounting Education, 29(4), 505-525. https://doi.org/10.2308/iace-50850

Debnath, M., Pandey, M., Chaplot, N., Gottimukkula, M. R., Tiwari, P. K., \& Gupta, S. N. (2012). Role of soft skills in engineering education: Students' perceptions and feedback. In Enhancing Learning and Teaching Through Student Feedback in Engineering. https://doi.org/10.1016/B978-1-84334-645-6.50004-5

Douglas A., J., \& Sigband, N. B. (1984). How effectively does the" new" accountant communicate? Perceptions by practitioners and academics. The Journal of Business Communication (1973), 21 (2), 15-24. https://doi.org/10.1177/002194368402100202

Gammie, E., \& Joyce, Y. (2009). Competence-based approaches to the assessment of professional accountancy training work experience requirements: The ICAS experience. Accounting Education: an international journal, 18(4-5), 443-466. https://doi.org/10.1080/09639280902719465

Gardner, C. T., Milne, M. J., Stringer, C. P., \& Whiting, R. H. (2005). Oral and written communication apprehension in accounting students: Curriculum impacts and impacts 
F. Carreira, R. Silva, A. Ferreira da Silva \& A. Martins Silva

Oral Communication Apprehension in Accounting Students: a study from Portugal

on academic performance. Accounting Education, 14(3), 313-336. https://doi.org/10.1080/06939280500077269

Geçer, A. K., \& Gümüş, A. E. (2010). Prediction of public and private university students' communication apprehension with lecturers. Procedia-Social and Behavioral Sciences, 2(2), 3008-3014. https://doi.org/10.1016/j.sbspro.2010.03.456

Gray, F. E. (2010). Specific oral communication skills desired in new accountancy graduates. Business communication quarterly, 73(1), 40-67. https://doi.org/10.1177/1080569909356350

Gray, F. E., \& Hamilton, L. (2014). Communication in accounting education, accounting education. An International Journal, 23(2), 115-118. doi:10.1080/09639284.2013.847327.

Hancock, A. B., Stone, M. D., Brundage, S. B., \& Zeigler, M. T. (2010). Public Speaking Attitudes: Does Curriculum Make a Difference? Journal of Voice, 24(3), 302-307. https://doi.org/10.1016/j.jvoice.2008.09.007

Hassall, T., Arquero, J. L., Joyce, J., \& Gonzalez, J. M. (2013). Communication apprehension and communication self-efficacy in accounting students. Asian Review of Accounting, 21 (2), 160-175. https://doi.org/10.1108/ARA-03-2013-0017

Hassall, T., Joyce, J., Arquero, J. L., \& Donoso, J. A. (2005). Priorities for the development of vocational skills in management accountants: A European perspective. Accounting Forum, 29(4), 379-394. https://doi.org/10.1016/j.accfor.2005.03.002

Hunsaker, F. G., Kelly, L., \& Duran, R. L. (1999). Sensation seeking and communication apprehension: Biological and genetic correlates of approaching or avoiding communication events. International Journal of Phytoremediation, 16(2), 121-130. https://doi.org/10.1080/08824099909388709

International Accounting Education Standards Board [IAESB]. (2014). Initial Professional Development - Professional Skills (Revised). New York, NY: International Education Standard (IES) 3. IFAC.

International Federation of Accountants - IFAC. (2010). Handbook of International Education Pronouncements 2010 Edition. New York, NY: IFAC.

Loureiro, M., Loureiro, N., \& Silva, R. (2020). Differences of Gender in Oral and Written Communication Apprehension of University Students. Education Sciences, 10(12). https://doi.org/10.3390/educsci10120379

Marcel, M. (2019). Communication Apprehension Across the Career Span. International Journal of Business Communication. https://doi.org/10.1177/2329488419856803

McCroskey, J. C., \& Beatty, M. J. (1984). Communication apprehension and accumulated communication state anxiety experiences: A research note. Communication Monographs, 51 (1), 79-84. https://doi.org/10.1080/03637758409390185

Arquero, J. L., Donoso, J. A., Hassall, T., \& Joyce, J. (2001). Vocational skills in the accounting professional profile: The Chartered Institute of Management Accountants (CIMA) employers' opinion. Accounting Education, 10(3), 299-313. https://doi.org/10.1080/09639280210122339 
Murphy, M., \& Weber, K. (2019). Confirmation of the Ability of the Personal Report of Communication Apprehension-24 (PRCA-24) to Predict Behavioral Indicators of Social Interaction. Communication Research Reports, 36(5), 393-403. https://doi.org/10.1080/08824096.2019.1683527

Nikolai, L. A. (1996). Suggestions for educational research on improving thinking and communication skills of accounting students. Journal of Accounting Education, 14(2), 193-197. https://doi.org/10.1016/0748-5751(96)00007-3

OECD (2015), Education at a Glance 2015: OECD Indicators (Summary), OECD Publishing, Paris. https://doi.org/10.1787/76d4bc29-en

OECD (2017), In-Depth Analysis of the Labour Market Relevance and Outcomes of Higher Education Systems: Analytical Framework and Country Practices Report, Enhancing Higher Education System Performance, OECD, Paris.

Parker, L. D. (2001). Back to the future: the broadening accounting trajectory. British Accounting Review, 33(4), 421-453. https://doi.org/doi:10.1006/bare.2001.0173

Pestana, M. H., \& Gageiro, J. N. (2014). Análise de dados para ciências Sociais. Complementaridade do SPSS 6 a EDIÇÃO Revista, Atualizada e Aumentada Maria Helena Pestana João nunes Gageiro. (September), 1-2. https://doi.org/10.13140/2.1.2491.7284

Porter, D. T. (1981). An Empirical Appraisal of The PRCA For Measuring Oral Communication Apprehension. Human Communication Research, 8(1), 58-71. https://doi.org/10.1111/j.1468-2958.1981.tb00656.x

Rose, H. M., Rancer, A. S., \& Crannell, K. C. (1993). The Impact of Basic Courses in Oral Interpretation and Public Speaking on Communication Apprehension. Communication Reports, 6(1), 54-60. https://doi.org/10.1080/08934219309367562

Ruchala, L. V., \& Hill, J. W. (1994). Reducing accounting students' oral communication apprehension: Empirical evidence. Journal of Accounting Education, 12(4), 283-303. https://doi.org/10.1016/0748-5751(94)90023-X

Siegel, G. \& Sorensen, J.E. (1999). Counting More, Counting Less: Transformations in the Management Accounting Profession-The 1999 Practice Analysis of Management Accounting. Institute of Management Accountants (USA).

Simons, K., Higgins, M., \& Lowe, D. (1995). A profile of communication apprehension in accounting majors: Implications for teaching and curriculum revision. Journal of Accounting Education, 13(2), 159-176. https://doi.org/10.1016/0748-5751(95)00001-3

Siriwardane, H. P., \& Durden, C. H. (2014). The communication skills of accountants: what we know and the gaps in our knowledge. Accounting Education, 23(2), 119-134. http://doi.org/10.1080/09639284.2013.847329

Siriwardane, H. P., Low, K. Y., \& Blietz, D. (2015). Making entry-level accountants better communicators: A Singapore-based study of communication tasks, skills, and attributes. Journal of Accounting Education, 33(4), 332-347. https://doi.org/10.1016/j.jaccedu.2015.08.001 
F. Carreira, R. Silva, A. Ferreira da Silva \& A. Martins Silva

Oral Communication Apprehension in Accounting Students: a study from Portugal

Smythe, M. J., \& Nikolai, L. A. (2002). A thematic analysis of oral communication concerns with implications for curriculum design. Journal of Accounting Education, 20(3), 163-181. ISSN :0748-5751

Tabassum, M., \& Hossain, M. (2020). Oral communication apprehension (OCA) among undergraduate accounting and journalism students in Bangladesh. Oral Communication Apprehension (OCA) among Undergraduate Accounting and Journalism Students in Bangladesh (January 30, 2020). http://dx.doi.org/10.2139/ssrn.3528396

Taber, K. S. (2018). The use of Cronbach's alpha when developing and reporting research instruments in science education. Research in Science Education, 48(6), 1273-1296. https://doi.org/10.1007/s11165-016-9602-2

Tverdushka, T., \& Stoliaruk, K. (2020). The impact of digitalization on work quality at the enterprise operational level. Technology Audit and Production Reserves, 4(4 (54)), 37-44. https://doi.org/10.15587/2706-5448.2020.211151

WEF (2020). Jobs of Tomorrow Mapping Opportunity in the New Economy. World Economic Forum.

Whitworth, R. H., \& Cochran, C. (1996). Evaluation of integrated versus unitary treatments for reducing public speaking anxiety. Communication Education, 45(4), 306-314. https://doi.org/10.1080/03634529609379060

Yong, A. G., Pearce, S., \& others. (2013). A beginner's guide to factor analysis: Focusing on exploratory factor analysis. Tutorials in Quantitative Methods for Psychology, 9(2), 7994. https://doi.org/10.20982/tqmp.09.2.p079 
F. Carreira, R. Silva, A. Ferreira da Silva \& A. Martins Silva

Oral Communication Apprehension in Accounting Students: a study from Portugal

Appendix 1 - Oral Communication Apprehension (OCA) English and translated versions

\begin{tabular}{|c|c|c|}
\hline & Original items & Translated items \\
\hline 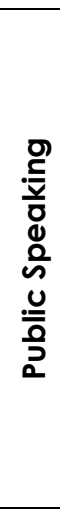 & $\begin{array}{l}\text { 1-I dislike participating in group discussions. } \\
\text { 2-Generally, I am comfortable while } \\
\text { participating in a group discussion. } \\
\text { 3-I am tense and nervous while } \\
\text { participating in group discussions. } \\
\text { 4-I like to get involved in group discussions. } \\
\text { 5-Engaging in a group discussion with new } \\
\text { people makes me feel tense and nervous. } \\
\text { 6-I am calm and relaxed while } \\
\text { participating in group discussions. }\end{array}$ & $\begin{array}{l}\text { 1. Eu não gosto de participar em discussões } \\
\text { de grupo /debates. } \\
\text { 2. Geralmente, estou confortável quando } \\
\text { participo numa discussão de grupo/debates. } \\
\text { 3. Estou tenso(a) e nervoso(a) quando } \\
\text { participo em discussões de grupo/debates. } \\
\text { 4. Eu gosto de me envolver em discussões de } \\
\text { grupo/debates. } \\
\text { 5. Participar em discussões de grupo/debates } \\
\text { com novas pessoas deixa-me tenso(a) e } \\
\text { nervoso(a). } \\
\text { 6. Estou calmo(a) e relaxado(a) quando } \\
\text { participo em discussões de grupo/debates. }\end{array}$ \\
\hline & $\begin{array}{l}\text { 7-Generally, I am nervous when I have to } \\
\text { participate in a meeting. } \\
\text { 8-Usually I am calm and relaxed while } \\
\text { participating in meetings. } \\
\text { 9-I am very calm and relaxed when I am } \\
\text { called upon to express an opinion at a } \\
\text { meeting. } \\
10-\text { am afraid to express myself at } \\
\text { meetings. } \\
11-\text { Communicating at meetings usually } \\
\text { makes me uncomfortable. } \\
\text { 12-I am very relaxed when answering } \\
\text { questions at a meeting. }\end{array}$ & $\begin{array}{l}\text { 7. Geralmente, fico nervoso(a) quando tenho } \\
\text { de participar numa reunião. } \\
\text { 8. Geralmente, estou calmo(a) e relaxado(a) } \\
\text { quando participo em reuniões. } \\
\text { 9. Estou muito calmo(a) e relaxado(a) quando } \\
\text { sou chamado(a) a expressar opinião numa } \\
\text { reunião. } \\
\text { 10. Tenho medo de me expressar nas reuniões. } \\
\text { 11. Comunicar em reuniões, geralmente, } \\
\text { deixa-me desconfortável. } \\
\text { 12. Estou muito relaxado(a) quando respondo } \\
\text { a perguntas numa reunião. }\end{array}$ \\
\hline & $\begin{array}{l}\text { 13-While participating in a conversation } \\
\text { with a new acquaintance, I feel very } \\
\text { nervous. } \\
\text { 14-I have no fear of speaking up in } \\
\text { conversations. } \\
\text { 15-Ordinarily I am very tense and nervous } \\
\text { in conversations. } \\
\text { 16-Ordinarily I am very calm and relaxed in } \\
\text { conversations. } \\
\text { 17-While conversing with a new } \\
\text { acquaintance, I feel very relaxed. } \\
\text { 18-I'm afraid to speak up in conversations. }\end{array}$ & $\begin{array}{l}\text { 13. Enquanto participo numa conversa com } \\
\text { um novo conhecido, sinto-me muito } \\
\text { nervoso(a). } \\
\text { 14. Eu não tenho medo de falar durante as } \\
\text { conversas em que participo. } \\
\text { 15. Normalmente, estou muito tenso(a) e } \\
\text { nervoso(a) durante as conversas. } \\
\text { 16. Normalmente, sou muito calmo(a) e } \\
\text { relaxado(a) durante as conversas. } \\
\text { 17. Ao conversar com um novo conhecido, } \\
\text { sinto-me muito relaxado(a). } \\
\text { 18. Tenho medo de falar durante as } \\
\text { conversas. }\end{array}$ \\
\hline 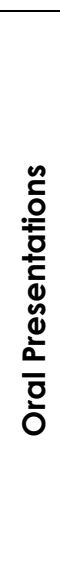 & $\begin{array}{l}\text { 19-I have no fear of giving a speech. } \\
20-C e r t a i n \text { parts of my body feel very } \\
\text { tense and rigid while giving a speech. } \\
21-\text { - feel relaxed while giving a speech. } \\
22-\text { My thoughts become confused and } \\
\text { jumbled when I am giving a speech. } \\
23-\text { I face the prospect of giving a speech } \\
\text { with confidence. } \\
24-\text { While giving a speech I get so nervous; } \\
\text { I forget facts I really know. }\end{array}$ & $\begin{array}{l}\text { 19. Eu não tenho medo de fazer uma } \\
\text { apresentação oral. } \\
\text { 20. Certas partes do meu corpo sentem-se } \\
\text { muito tensas e rígidas ao fazer uma } \\
\text { apresentação } 21 \text {. oral. } \\
\text { 22. Sinto-me relaxado(a) enquanto faço uma } \\
\text { apresentação oral. } \\
\text { 23. Os meus pensamentos ficam confusos e } \\
\text { desordenados quando estou a fazer uma } \\
\text { apresentação oral. } \\
\text { 24. Eu enfrento a perspetiva de fazer uma } \\
\text { apresentação oral com confiança. } \\
\text { 25. Ao fazer uma apresentação oral, fico tão } \\
\text { nervoso(a) que me esqueço dos factos que } \\
\text { realmente conheço. }\end{array}$ \\
\hline
\end{tabular}


F. Carreira, R. Silva, A. Ferreira da Silva \& A. Martins Silva

Oral Communication Apprehension in Accounting Students: a study from Portugal

Scoring:

Public Speaking=18 - (1) + (2) - (3) + (4) - (5) + (6)

Meetings $=18-(7)+(8)+(9)-(10)-(11)+(12)$

Group Talking $=18-(13)+(14)-(15)+(16)+(17)-(18)$

Oral Presentations $=18+(19)-(20)+(21)-(22)+(23)-(24)$

Overall OCA $=$ Public Speaking + Meetings + Group Talking + Oral Presentations

Source: McCroskey, Beatty, Kearney, \& Plax (1985)

Appendix 2 - Exploratory Factor Analysis (EFA) of PRCA

\begin{tabular}{|c|c|c|c|c|c|}
\hline \multicolumn{6}{|l|}{ Round Component Matrix } \\
\hline \multirow{2}{*}{ Constructs } & \multirow{2}{*}{ Variables } & \multicolumn{4}{|c|}{ Factors } \\
\hline & & 1 & 2 & 3 & 4 \\
\hline \multirow[t]{6}{*}{ Public Speaking } & Speakingl & .757 & & & \\
\hline & Speaking2 & .752 & & & \\
\hline & Speaking3 & .700 & & & \\
\hline & Speaking4 & .802 & & & \\
\hline & Speaking5 & .750 & & & \\
\hline & Speaking6 & .801 & & & \\
\hline \multirow[t]{6}{*}{ Meetings } & Meetings 1 & & .772 & & \\
\hline & Meetings2 & & .857 & & \\
\hline & Meetings3 & & .677 & & \\
\hline & Meetings4 & & .715 & & \\
\hline & Meetings5 & & .709 & & \\
\hline & Meetings6 & & .887 & & \\
\hline \multirow[t]{6}{*}{ Group Talking } & Talking 1 & & & .650 & \\
\hline & Talking2 & & & .558 & \\
\hline & Talking3 & & & .788 & \\
\hline & Talking4 & & & .684 & \\
\hline & Talking5 & & & .691 & \\
\hline & Talking6 & & & .829 & \\
\hline \multirow[t]{6}{*}{ Oral Presentations } & Presentations 1 & & & & .785 \\
\hline & Presentations2 & & & & .780 \\
\hline & Presentations3 & & & & .706 \\
\hline & Presentations4 & & & & .798 \\
\hline & Presentations5 & & & & .735 \\
\hline & Presentations6 & & & & .713 \\
\hline Cronbach Alpha Value & & .850 & .835 & .805 & .781 \\
\hline
\end{tabular}


F. Carreira, R. Silva, A. Ferreira da Silva \& A. Martins Silva Oral Communication Apprehension in Accounting Students: a study from Portugal

\begin{tabular}{|c|c|c|c|c|c|c|}
\hline & & Sum of Squares df & & $\begin{array}{l}\text { Mean } \\
\text { Square }\end{array}$ & $F$ & Sig. \\
\hline \multirow[t]{3}{*}{ PublicSpeaking } & Between Groups & 1996,819 & 43 & 46,438 & 1,927 &, 000 \\
\hline & Within Groups & 18505,008 & 768 & 24,095 & & \\
\hline & Total & 20501,826 & 811 & & & \\
\hline \multirow[t]{3}{*}{ Meetings } & Between Groups & 2350,010 & 43 & 54,651 & 2,132 &, 000 \\
\hline & Within Groups & 19682,427 & 768 & 25,628 & & \\
\hline & Total & 22032,437 & 811 & & & \\
\hline \multirow[t]{3}{*}{ GroupTalking } & Between Groups & 1696,322 & 43 & 39,449 & 1,711 & ,004 \\
\hline & Within Groups & 17711,968 & 768 & 23,062 & & \\
\hline & Total & 19408,291 & 811 & & & \\
\hline \multirow[t]{3}{*}{ OralPresentations } & Between Groups & 1999,929 & 43 & 46,510 & 1,739 &, 003 \\
\hline & Within Groups & 20538,672 & 768 & 26,743 & & \\
\hline & Total & 22538,601 & 811 & & & \\
\hline
\end{tabular}

